\title{
Comparative Investment Analysis of Industries Development in Russia and Germany
}

\author{
Natalia Chistyakova \\ Department of Management \\ Tomsk Polytechnic University \\ Tomsk, Russia \\ worldperson@mail.ru \\ Tatiyana Gromova \\ Department of Management \\ Tomsk Polytechnic University \\ Tomsk, Russia \\ tv-grom@tpu.ru \\ Alena Dudnikova \\ Tomsk Polytechnic University \\ Tomsk, Russia \\ oved55@yandex.ru
}

\begin{abstract}
The investment policies in some of manufacturing industries in Russia and Germany are described in article. Most appropriate industries for such an analysis are electronic and optical manufacturing and electrical equipment production and manufacturing of motor vehicles, trailers and semi-trailers. Authors make comparative analyses of investment in manufacturing and changes in production value in these industries. Information base of research are Russian Statistical data service and Eurostat. Results allow making the following conclusion. Considering these parameters Russia manufacturing industry lags far behind Germany. A major problem lack of investment that in terms of sanctions and limited external financing will pose serious problems for the development of subDL and DM sector of manufactures in Russia
\end{abstract}

Keywords- investment; manufacturing industries; comparative analysis

\section{INTRODUCTION}

Nowadays many researchers have proposed various hypotheses concerning the analysis of the preconditions for economic growth, including ones in the innovation economy. The authors consider important to analyze the impact of such a variable as an investment in fixed assets (machinery and equipment), and their effect on increase in turnover of the enterprise in the context of industries. The main scientific idea in this article is the assumption that in developed countries, increased investment in fixed assets for several manufacturing industry always leads to an increase in turnover growth in these industries, which in turn is an important stimulus for economic development. It seems interesting to make the comparative analysis of Russia and leading EU country - Germany.

\author{
Vladislav Spitsin* \\ Department of Management \\ Tomsk Polytechnic University \\ Tomsk, Russia \\ spitsin_vv@mail.ru \\ *Corresponding author
}

Natalia Shabaldina

Department of Information Technology

Tomsk State University

Tomsk, Russia

shabaldina@mail.ru

\section{LITERATURE REVIEW}

Many foreign researchers carried out analysis of the impact of investment in fixed assets. Most of the work is devoted to the identification of correlations between various factors and investment in fixed assets.

Arndt, Bush, Schnitzer, 2007 [1]; UNSTAD 2006 [2]; Baker \& Muendler, 2006 [3] proves the existence of a possible positive impact on the increase in the value of fixed capital (fixed assets) as a result of foreign direct investment in Germany only in the long term . Simulating different variables, including the increase in turnover of German companies, with a small time lag, a direct relationship could not be traced.

Okwo, 2012 [4] has studied the relationship between investment in fixed assets and operating profit, which was not confirmed by the study in the Nigerian sector of the food industry. Svetlana \& Aaro, 2012 [5] analyzed more than 8074 companies in six countries of the EU and concluded that the absence of a strong negative or positive relationship between investment intensity and the rate of return on assets. While Abarbanell \& Bushee, 1997, 1998 [6,7]; Henessy and Levy, 2002 [8]; in their work proved a strong inverse relationship between the rate of investment and profitability of the companies.

A detailed analysis of the German case had Deutsche Bank, studying the importance of investment in fixed assets, which, along with other parameters studied the impact of investments in index products shipped by industry (all industries are analyzed and plotted for each correlation). In the research authors did not found strong significant correlation between these parameters, fixing a large scatter of data with different 
values. For example, in the field of mechanical engineering and transport, this dependence is observed, while in the food, textile, and others industries dependence is absent.

Considering this fact, it seems interesting to make an analysis on the basis of Russian statistic data that will clarify or refute these studies of German scientists. This paper is devoted to a comparative analysis of investment in machinery and equipment and the production value of Russian and German industries.

\section{METHODOLOGY OF RESEARCH}

Objects of the research are the follows. The countries: Russia and Germany. Manufacturing industries:

1) According to Eurostat methodology (for Germany):

C26 - Manufacture of computer, electronics and optical products

C27 - Manufacturing of electrical equipment;

C29 - Manufacture of motor vehicles, trailers and semitrailers

C30 - Manufacture of other transport equipment

2) According to the Russian statistics methodology:

DL - Manufacture of electrical and optical equipment

DM - Manufacture of other transport equipment and motor vehicles

Study period: 2009 - 2012 years.

Information base of research: Eurostat [9], Russian and international statistical databases [10], the data obtained by special request to the Russian Federal State Statistics Service.

The algorithm of research methodology:

1. Calculated the ratio of the investment on machinery and equipment and production value in countries in sectors DL and DM (Russia) and C26+27, C29+C30 (Germany).

2. The analysis of the index dynamics in the context of countries (Russia and Germany) and manufacturing sectors in crisis and post-crisis period (2009-2012).

4. Calculate the rate of growth of the investment by countries and sectors DL and DM.

5. A study the relationship between the growth rate of production value and investment in fixed assets in industries.

\section{RESULT OF RESEARCH}

A. Comparative analysis of the relationship between the growth rate of production value and the growth of investment in equipment.

The growth rate of the production value and investment in machinery and equipment sub-DL and DM Russia are shown in Fig. 1 and 2 and C26+27, C29+C30 for Germany from Eurostat are shown in Fig.3 and 4

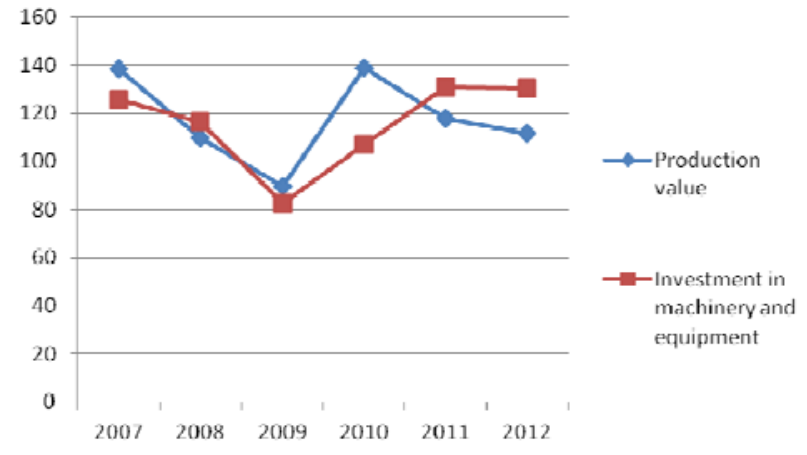

FIGURE I. GROWTH RATE OF INVESTMENT AND PRODUCTION VALUE FOR SECTOR DL, RUSSIA, \%

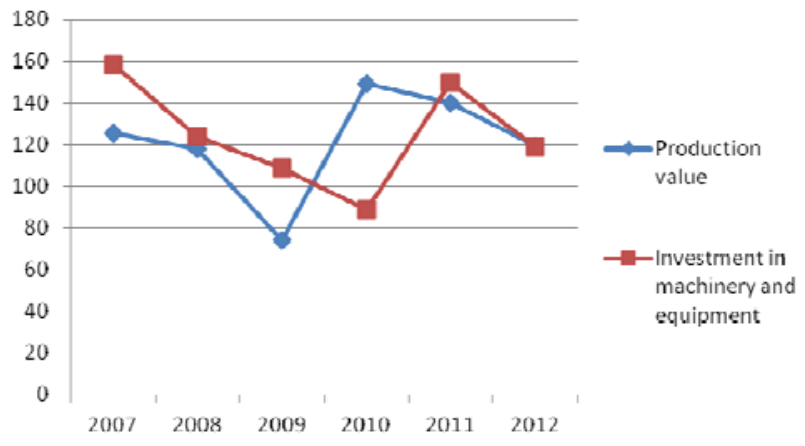

FIGURE II. GROWTH RATE OF INVESTMENT AND PRODUCTION VALUE FOR SECTOR DM, RUSSIA, \%

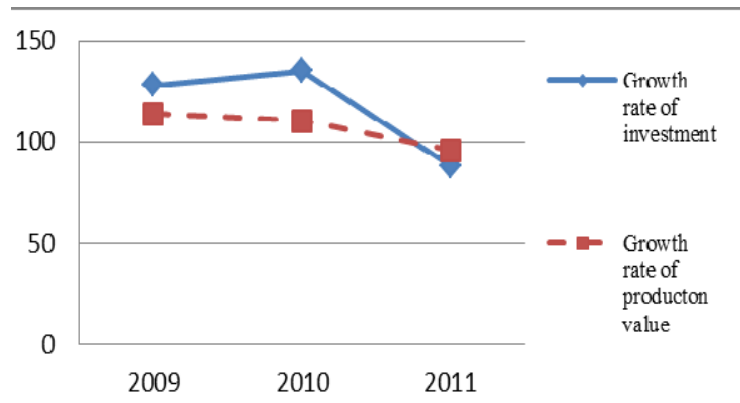

FIGURE III. GROWTH RATE OF INVESTMENT AND PRODUCTION VALUE FOR SECTOR C26+27, GERMANY, \%

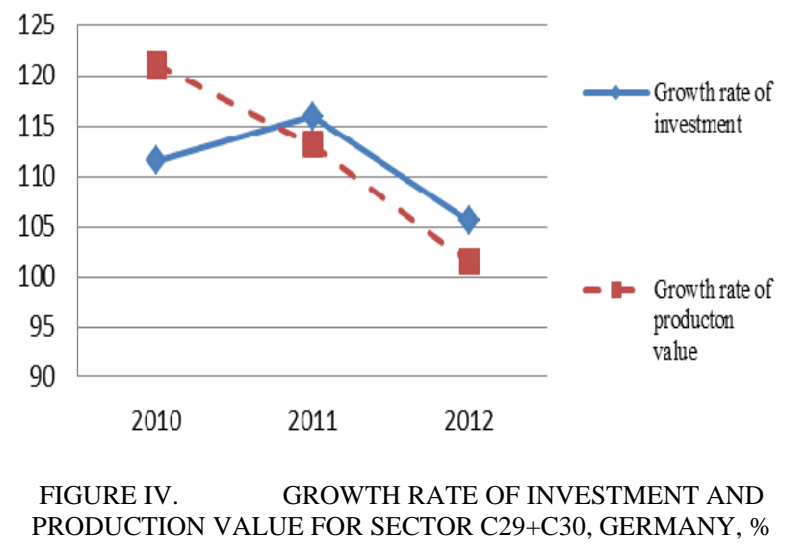


Despite of certain similarities of indicators behavior under subsection DL, linear regression equation for Russia does not reveal significant relationship between them $(R 2=0,23)$. Under subsection DM situation is even more complicated, there probably a time lag in Russia. Thus, the analysis confirmed the problems with the identification of dependencies between indicators. Further study in this area requires.

\section{B. Analysis of the differences in the sectorial structure of the manufacturing industry in Russia and abroad}

Share of production value and investment in machinery and equipment sub-sector DL and DM for Russia, and C26+27 \& C296C30, calculated for the manufacturing industry (D), presented in the table 1-2.

It is obvious that there are serious imbalances in Russia. Share of production value in Russia significantly exceeds the share of investments (DL - three times, DM - almost twice).

TABLE I. STATISTICAL ANALYSES OF GERMAN MANUFACTURING INDICATORS

\begin{tabular}{|c|c|c|c|c|}
\hline Germany & 2009 & 2010 & 2011 & 2012 \\
\hline $\begin{array}{l}\text { Investment } \\
\text { C26+27, ths. } \\
\text { EUR }\end{array}$ & 3863,9 & 4947,3 & 6686,8 & 5908,9 \\
\hline $\begin{array}{l}\text { Investment total } \\
\text { C, ths. EUR }\end{array}$ & 42358,4 & 43581,9 & 50693,3 & 51506,5 \\
\hline $\begin{array}{l}\text { Share of } \\
\text { investment } \\
\mathrm{C} 26+\mathrm{C} 27, \%\end{array}$ & 9,1 & 11,3 & 13,2 & 11,5 \\
\hline $\begin{array}{l}\text { Production } \\
\text { value C29+C30, } \\
\text { ths. EUR }\end{array}$ & 137749,2 & 156818,1 & 173221,4 & 166308,2 \\
\hline $\begin{array}{l}\text { Production } \\
\text { value total C., } \\
\text { ths. EUR }\end{array}$ & 1378217 & 1570396,6 & 1759678 & 1755199 \\
\hline $\begin{array}{l}\text { Share of } \\
\text { Production } \\
\text { value } \\
\text { C29+C30, \% }\end{array}$ & 10,0 & 10,0 & 9,8 & 9,5 \\
\hline
\end{tabular}

TABLE II. STATISTICAL ANALYSES OF RUSSIAN MANUFACTURING INDICATORS

\begin{tabular}{|c|c|c|c|c|}
\hline Russia & 2009 & 2010 & 2011 & 2012 \\
\hline $\begin{array}{l}\text { Investment } \mathrm{Dl} \text {, } \\
\text { mln. rubles }\end{array}$ & 17671,5 & 18853,4 & 24647,9 & 32180,9 \\
\hline $\begin{array}{l}\text { Investment } \\
\text { total } \mathrm{D}, \mathrm{mln} \text {. } \\
\text { rubles }\end{array}$ & 943633,7 & 1008443,3 & 1223244,0 & 1374321 \\
\hline $\begin{array}{ll}\text { Share } & \text { of } \\
\text { investment } & \\
\text { DL , \% } & \end{array}$ & 1,9 & 1,9 & 2,0 & 2,3 \\
\hline $\begin{array}{l}\text { Production } \\
\text { value } \mathrm{DM}, \mathrm{mln} \text {. } \\
\text { rubles }\end{array}$ & 816583,8 & 1131548,8 & 1329329,4 & 1481610 \\
\hline $\begin{array}{l}\text { Production } \\
\text { value } \mathrm{D}, \mathrm{mln} . \text {. } \\
\text { rubles }\end{array}$ & 14351985 & 18880737 & 22813280 & 25110611 \\
\hline $\begin{array}{l}\text { Share of } \\
\text { Production } \\
\text { value DM,\% }\end{array}$ & 5,7 & 6.0 & 5,8 & 5,9 \\
\hline
\end{tabular}

While in Germany there is opposite situation and the share of investment exceeds the share of production value. This means high capital intensity of other manufacturing industries of Russia (oil refining, metallurgy, etc.). Considering political crisis and economic sanctions external financing investments channels in Russia are severely limited. It means that a fixed amount of internal resources will be redistributed to other industries. Under these conditions create the prerequisites for advancing innovation and investment development of subsection DL and DM would be extremely difficult, because the absence of investment resources.

\section{CONCLUSION}

The leader of the ratio of these indicators is Germany, which is significantly ahead of Russia. Regression did not reveal a strong direct relationship between indicators of "investment in machinery and equipment" and "production value" in the case of Russia. Although there is no linear relationship between the growth rates of these indicators. Considering these parameters Russia manufacturing industry lags far behind Germany. A major problem lack of investment that in terms of sanctions and limited external financing will pose serious problems for the development of sub-DL and DM sector of manufactures in Russia.

\section{REFERENCES}

[1] Arndt, Bush, Schnitzer, (2007) FDI and Domestic Investment: An Industry-Level View.Governance and the Efficiency of Economic System, July 2007.

[2] United Nations Conference on Trade and Development (UNCTAD) (2006).World Investment Report 2006: FDI from Developing and Transition Economies: Implications for development. New York and Geneva.

[3] Becker, S.O., and M.-A. Muendler (2006). The Effects of FDI on Worker Displacement. University of Munich and UC San Diego. Mimeo.

[4] Okwo I.M., Ugwunta D.O., Nweze A.U. (2012) Investment in Fixed Assets and Firm Profitability: Evidence from the Nigerian Brewery Industry. European Journal of Business and Management Vol. 4, No.20, 10-17

[5] Svetlana and Aaro (2012) Does Investment Intensity Impact Company Profitability? A Cross- Country Empirical Study. 2nd International Conference on Economics, Trade and Development IPEDR vol.36 IACSIT Press, Singapore

[6] Abarbanell, J.S., and Bushee, B.J. (1997). Fundamental Analysis, Future Earnings, and Stock Prices. Journal of Accounting Research, Vol. 35, No.1, 1-24.

[7] Abarbanell, J.S., and Bushee, B.J. (1998). Abnormal Returns to a Fundamental Analysis Strategy. The Accounting Review, Vol. 73, No. 1, 19-45.

[8] Levy A. and Hennessy C. (2007) Why does capital structure choice vary with macroeconomic conditions? Journal of Monetary Economics 54, 1545-1564.

[9] Eurostat. Europian statistic database service. http://ec.europa.eu/eurostat/en/web/products-datasets/-/HLTH_DE060

[10] Russian Federal State Statistical Data Base. http://www.gks.ru/ 